\title{
Urinary excretion of purine derivatives as an index of microbial protein synthesis in the camel (Camelus dromedarius)
}

\author{
Abdelhai Guerouali ${ }^{1}$, Youssef El Gass ${ }^{1}$, Joaquim Balcells ${ }^{2}$, Alvaro Belenguer ${ }^{2}$ and John Nolan ${ }^{3}$ \\ ${ }^{1}$ Department of Animal Physiology, Institut Agronomique et Vétérinaire Hassan II, PO Box 6202, Rabat, Morocco \\ ${ }^{2}$ Departamento de Producción Animal y Ciencia de los Alimentos, Facultad de Veterinaria, Miguel Servet 177, Zaragoza, \\ 50013, Spain \\ ${ }^{3}$ School of Rural Science and Agriculture, University of New England, Armidale, NSW 2351, Australia
}

(Received 23 October 2003 - Revised 7 April 2004 - Accepted 22 April 2004)

Five experiments were carried out to extend knowledge of purine metabolism in the camel (Camelus dromedarius) and to establish a model to enable microbial protein outflow from the forestomachs to be estimated from the urinary excretion of purine derivatives (PD; i.e. xanthine, hypoxanthine, uric acid, allantoin). In experiment 1 , four camels were fasted for five consecutive days to enable endogenous PD excretion in urine to be determined. Total PD excretion decreased during the fasting period to 267 (SE 41.5) $\mu \mathrm{mol} / \mathrm{kg}$ body weight (W) ${ }^{075}$ per d. Allantoin and xanthine + hypoxanthine were consistently 86 and $6.1 \%$ of total urinary PD during this period but uric acid increased from $3.6 \%$ to $7.4 \%$. Xanthine oxidase activity in tissues (experiment 2 ) was ( $\mu \mathrm{mol} / \mathrm{min}$ per $\mathrm{g}$ fresh tissue) 0.038 in liver and 0.005 in gut mucosa but was not detected in plasma. In experiment 3 , the duodenal supply of yeast containing exogenous purines produced a linear increase in urinary PD excretion rate with the slope indicating that 0.63 was excreted in urine. After taking account of endogenous PD excretion, the relationship can be used to predict purine outflow from the rumen. From the latter prediction, and also the purine:protein ratio in bacteria determined in experiment 5 , we predicted the net microbial outflow from the rumen. In experiment 4 , with increasing food intake, the rate of PD excretion in the urine increased linearly by about $11.1 \mathrm{mmol} \mathrm{PD} / \mathrm{kg}$ digestible organic matter intake (DOMI), equivalent to $95 \mathrm{~g}$ microbial protein $/ \mathrm{kg}$ DOMI.

Purine derivatives: Xanthine oxidase: Microbial protein: Camels

The urinary excretion of purine derivatives (PD; i.e. allantoin, uric acid, hypoxanthine and xanthine) is proportional to the flow of purines into the small intestine. The relationship has been used as a predictor of microbial outflow from the rumen of sheep (Chen et al. 1990; Balcells et al. 1992), cattle (Verbic et al. 1990; Orellana Boero et al. 2001), goats (Belenguer et al. 2002) and zebu cattle (Bos indicus; Pimpa et al. 2001). This technique has potential for use in other ruminant species of economic significance, provided prediction equations are defined to take account of differences in purine metabolism among species (Chen et al. 1996) and even among breeds of the same species. For the camel (Camelus dromedarius) there is only limited information on purine metabolism (for example, Mura et al. 1986).

The present study was designed to extend our understanding of purine metabolism in the camel and to establish a model for use in estimating net microbial protein outflow from the rumen of the camel. Five experiments were carried out. In experiment 1 , endogenous urinary PD excretion was determined in fasting camels. In experiment 2 , the activity in different tissues of xanthine oxidase (XO), a key enzyme of purine base (PB) metabolism, was determined. In experiment 3 , a relationship was established between the duodenal infusion of exogenous purines and the excretion of PD in urine. In experiment 4 a relationship between food intake and the urinary excretion of PD was determined, and in experiment 5 chemical composition of bacteria from camel forestomachs was determined.

\section{Material and methods \\ Experiment 1: urinary excretion of purine derivatives during fasting}

Four female camels (478 (SE 45) kg) were individually penned with restricted movement. They were offered a mixed diet composed of barley grain $(3 \mathrm{~kg} ; 13.1 \mathrm{MJ}$ metabolisable energy (ME)/kg DM; $11.9 \%$ crude protein), sunflower-seed meal (1 kg; 7.28 MJ ME/kg DM; $25.9 \%$ crude protein) and wheat straw $(2 \mathrm{~kg} ; 6.82 \mathrm{MJ} \mathrm{ME} / \mathrm{kg}$ $\mathrm{DM} ; 4.3 \%$ crude protein). The camels were adapted to

\footnotetext{
Abbreviations: DOMI, digestible organic matter intake; ME, metabolisable energy; PB, purine base; PMSF, phenylmethylsulfonyl fluoride; PD, purine derivative; W, body weight; XO, xanthine oxidase.

* Corresponding author: Dr J. Balcells, fax +34 9767615 90, email balcells@posta.unizar.es
} 
this diet for 2 weeks. Their daily ration was then reduced to $60 \%$ for 2 days and to $30 \%$ for another 2 days after which the animals were fasted for a further $5 \mathrm{~d}$. Urine was collected during the last $2 \mathrm{~d}$ of feeding, the restricted feeding and during the fasting period. A plastic bag collector was glued around the vulva of each camel and connected to tubing that directed each day's urine to a bucket to which $1 \mathrm{M}-\mathrm{H}_{2} \mathrm{SO}_{4}(250 \mathrm{ml})$ had been added to ensure a final $\mathrm{pH}$ of 2-3. At the end of each $24 \mathrm{~h}$ period, tap water was added to each bucket to bring the contents to the same mass for all animals and then subsamples (about $50 \mathrm{ml}$ ) were taken and stored at $-20^{\circ} \mathrm{C}$ for later analysis.

\section{Experiment 2: xanthine oxidase activity in plasma, liver and intestine}

The activity of XO was determined in samples of plasma from blood taken before slaughter, and in post-slaughter liver and intestinal tissues from three 2-year-old male camels (previous nutritional status unknown) killed at a local slaughterhouse. The blood samples were collected into heparinised tubes, centrifuged at $5000 \mathrm{~g}$ for $15 \mathrm{~min}$ and the plasma was removed and analysed within $3 \mathrm{~h}$ from the time of collection. Procedures for preparing liver and intestinal mucosa samples were adapted from those described by Furth-Walker \& Amy, (1987) and Reeds et al. (1997), respectively. Samples were washed in cold $0.15 \mathrm{M}-\mathrm{KCl}$, and $1 \mathrm{~g}$ tissue was homogenised in $0.5 \mathrm{~mm}$-EDTA $(9 \mathrm{ml})$ in $0.05 \mathrm{M}-\mathrm{K}_{2} \mathrm{HPO}_{4}(\mathrm{pH} 7.5)$ and centrifuged at $35000 \mathrm{~g}$ for $30 \mathrm{~min}$ at $4^{\circ} \mathrm{C}$. The supernatant fraction was dialysed against the EDTA- $\mathrm{KH}_{2} \mathrm{PO}_{4}$ buffer for $24 \mathrm{~h}$ and centrifuged again at $35000 \mathrm{~g}$ for $30 \mathrm{~min}$ at $4^{\circ} \mathrm{C}$. This supernatant fraction was used for the enzyme assay. Intestinal samples were taken from the duodenum and the lumen washed with cold $0 \cdot 15 \mathrm{M}-\mathrm{KCl}$. Samples were then immediately frozen in liquid $\mathrm{N}_{2}$ and defrosted within $2 \mathrm{~h}$ at $4^{\circ} \mathrm{C}$. Then the lumen was washed with 0.05 M-HEPES buffer ( $\mathrm{pH} \mathrm{7.5)} \mathrm{containing} \mathrm{0.25} \mathrm{mM-EDTA} \mathrm{and}$ $0.25 \mathrm{~mm}$-phenylmethylsulfonyl fluoride (PMSF). Intestinal mucosa $(1 \mathrm{~g})$ was removed by finger pressure along the intestine, and the mucosal tissue was collected at the bottom in $9 \mathrm{ml}$ HEPES-EDTA-PMSF buffer. The mucosal tissue was then processed as for liver samples but using the HEPES-EDTA-PMSF buffer. The activity of $\mathrm{XO}$ was determined from the rate of uric acid production when xanthine $(0.5 \mathrm{ml} / 1.5 \mathrm{mmol})$ was incubated with the tissue extracts.

\section{Experiment 3: relationship between duodenal input and urinary output of purine compounds}

Two non-lactating female camels (5 years old, about $400 \mathrm{~kg}$ ), each fitted with a T-shaped duodenal cannula (Silkolatex T-Tube; Rüsch, Kernen, Germany), were used in this experiment. The surgery was done under general anaesthesia (Xylazine $5 \%, 0.5 \mathrm{ml} / 100 \mathrm{~kg}$ body weight (W)). Each cannula was placed in the duodenal bulb and its tubing was kept under the skin with about $50 \mathrm{~mm}$ exterior to the animal. The cannula was sited in the body wall about $100 \mathrm{~mm}$ down from the rachis and $50 \mathrm{~mm}$ behind the last rib on the right side of the abdomen. After the surgery, the animals were kept in individual pens and fed at a maintenance level (0.314 MJ ME/kg $\mathrm{W}^{0.75}$; Guerouali \& Zine Filali, 1992) for several weeks before and during the experiment on a diet $(2 \cdot 8-2.9 \mathrm{~kg}$ DM) composed of $50 \%$ barley grain; $17 \%$ sunflowerseed meal and $33 \%$ wheat straw. The experiment lasted $20 \mathrm{~d}$ and the relationship between the duodenal input of purines and the urinary output of PD was determined. To modify the flow of PB into the duodenum, solutions containing increasing concentrations of RNA from Torula yeast (Sigma Co., St Louis, MO, USA) were continuously infused into the duodenum in four successive $5 \mathrm{~d}$ periods at $1.4 \mathrm{ml} / \mathrm{min}$ using a peristaltic pump (Isomatec, mp-ge, Zurich, Switzerland). The rates of infusion of PB were 0, $18.7,36.3$ and $55 \mathrm{mmol} / \mathrm{d}$ in periods 1 to 4 , respectively, and were intended to simulate the microbial purine flows into the duodenum expected if food intakes were varied from one to three times maintenance. Urine was collected during the last $3 \mathrm{~d}$ of each $5 \mathrm{~d}$ period. RNA solutions were prepared by dissolving the yeast with 2 litres of $0.005 \mathrm{M}$ $\mathrm{NaOH}$ at $40^{\circ} \mathrm{C}$. Once the yeast was diluted, the $\mathrm{pH}$ was adjusted to that detected in the duodenal digesta $(\mathrm{pH} 3-$ 4). Urine was collected over three $24 \mathrm{~h}$ periods into a bucket containing $1 \mathrm{M}-\mathrm{H}_{2} \mathrm{SO}_{4}(50 \mathrm{ml}$; to maintain $\mathrm{pH}<3)$ using the procedure described in experiment 1 .

\section{Experiment 4: urinary excretion of purine derivatives at different levels of food intake}

The experiment was conducted on four camels (400 (SE $30) \mathrm{kg}$ ). Before the experiment, the camels were fed individually for 2 weeks, ad libitum, on a diet composed of $50 \%$ barley grain, $12 \%$ sunflower-seed meal, $37 \%$ ground straw with $1 \%$ of a mineral and vitamin supplement. The food was offered twice daily at 09.00 and 16.00 hours in two equal meals and the camels had free access to drinking water. A $4 \times 4$ Latin square design was used with four $21 \mathrm{~d}$ feeding periods and four feeding levels corresponding to $40,60,80$ and $100 \%$ of the lowest level of voluntary intake recorded in the preexperimental period. During the last week of each period, total collections of urine and faeces were made daily. Urine samples were taken and stored as described in experiment 1. A subsample (10\%) of each day's faeces was kept in polyethylene bags and stored at $4^{\circ} \mathrm{C}$ for later analysis.

\section{Experiment 5: relationship between purine bases and nitrogen in bacteria from the camel forestomachs}

Rumen digesta were taken at the slaughterhouse from the camels used in experiment 2 for the isolation of microbial materials. The digesta $(250 \mathrm{ml})$ were squeezed through four layers of surgical gauze and a bacterial fraction was isolated by differential centrifugation. First, the digesta were centrifuged at $500 \mathrm{~g}$ for $5 \mathrm{~min}$ to precipitate the particulate material and the resulting supernatant fraction was centrifuged at $20000 \mathrm{~g}$ for $20 \mathrm{~min}$ at $4^{\circ} \mathrm{C}$ to deposit the bacterial fraction. Then the bacterial material was suspended in physiological saline solution $(9 \mathrm{~g} \mathrm{NaCl} / \mathrm{l})$ 
and again centrifuged at $20000 \mathrm{~g}$ for $20 \mathrm{~min}$ at $4^{\circ} \mathrm{C}$. The washed microbial pellet was freeze-dried and stored for subsequent analyses.

\section{Chemical analysis}

Food, faeces and microbial extracts were analysed for organic matter, DM, and total $\mathrm{N}$ using standard procedures (Association of Official Analytical Chemists, 1980). In experiment 3, the PD concentrations in urine were determined using HPLC (Balcells et al. 1992). PB in yeast RNA and in rumen bacteria were analysed by the procedure of Martín-Orúe et al. (1995). In experiments 1 and 4, urinary allantoin concentrations were determined by the method of Young \& Conway (1942), and uric acid concentrations by a phosphotungstic acid method adapted from a method of Technicon Instruments Co. (1979). Xanthine + hypoxanthine concentrations were determined from the increase in uric acid concentration that occurred after treatment of samples with XO.

\section{Statistical analysis}

In experiment 1 , to study the effect of animal and time on the urinary excretion of PD during fasting, the data were analysed as repeated observations on each experimental unit (animal). An orthogonal set of contrasts over time, comparing each daily mean with the mean of the following period, was used to partition the error sum of squares into components associated with each contrast (Rowell \& Walters, 1976). In experiment 2 , only means and standard errors are presented. In experiment 3, a linear model $(y=\mathrm{a}+\mathrm{b} x)$ was fitted to the data for the urinary excretion of $\mathrm{PD}(x ; \mathrm{mmol} / \mathrm{d}) v$. duodenal $\mathrm{PB}$ infusion rate $(x ; \mathrm{mmol} /$ d), by procedures described by Steel \& Torrie (1980). In experiment 4 , the data were analysed as a Latin square design using the model:

$$
y_{\mathrm{ijk}}=\mu+D_{\mathrm{i}}+A_{\mathrm{j}}+P_{\mathrm{k}}+\varepsilon_{\mathrm{ijk}},
$$

where $D_{\mathrm{i}}, A_{\mathrm{j}}$, and $P_{\mathrm{k}}$ were the main effects that were contrasted against the residual error term $(\varepsilon)$ and $D$ represents diets (treatments), $A$ represents animals and $P$ represents periods. A linear regression model was fitted to the data for the rate of urinary excretion of PD $(y ; \mathrm{mmol} / \mathrm{d})$ and digestible organic matter intake (DOMI) $(x ; \mathrm{kg} / \mathrm{d})$ as previously described.

\section{Results \\ Experiment1: urinary excretion of purine derivatives during fasting}

Individual values for the daily excretion of PD (allantoin, uric acid, xanthine+hypoxanthine) during fasting are presented in Table 1 and changes over time are given in Fig. 1. Total PD excretion, which was mainly present as allantoin, decreased significantly as intake decreased with food restriction to lower and constant values from the third to the fifth day of fasting. PD excretion $(\mu \mathrm{mol} / \mathrm{kg}$ $\mathrm{W}^{075}$ ) over this period decreased from 549 (SE 44.5) to 267 (SE 33.5) and from 493 (SE 36.6) to 231 (SE 43.4) for PD and allantoin, respectively. The relative contributions of allantoin and xanthine + hypoxanthine to total PD during the pre-fasting and fasting periods showed only minor changes $(89 v .86 \%$ and 6.4 v. $6.1 \%$ of total $\mathrm{PD}$, respectively) whereas the uric acid proportion apparently increased from 3.6 to $7.4 \%$ in the same period.

The minimum (basal) excretion of total PD in urine during fasting was 267 (SE 33.5) $\mu \mathrm{mol} / \mathrm{kg} \mathrm{W}^{075}$ (range $212-300 \mu \mathrm{mol} / \mathrm{kg}$ ). Urinary creatinine excretion averaged 329 (SE 48.0) $\mu \mathrm{mol} / \mathrm{kg} \mathrm{W}^{0.75}$ and was not affected by food restriction or fasting.

\section{Experiment 2: xanthine oxidase activity in plasma and tissues of camels}

The production of uric acid when xanthine was incubated with plasma or tissue extracts from camels, an indicator of XO activity, is given in Fig. 2. The calculated XO activities in liver $(0.038$ (SE 0.0009$) \mu \mathrm{mol} / \mathrm{min}$ per $\mathrm{g}$ ) were higher than for gut mucosa (0.005 (SE 0.0012) $\mu \mathrm{mol} / \mathrm{min}$ per $\mathrm{g}$ ) but there was no detectable activity in plasma.

\section{Experiment 3: relationship between duodenal input and urinary output of purine compounds}

The continuous infusion of RNA solution was apparently well accepted by the two animals and there were no noticeable changes in feeding behaviour. Mean values for the daily excretion of PD in response to increasing rates of infusion of PB into the duodenum are given in Table 2 . The total urinary excretion of PD $(y ; \mathrm{mmol} / \mathrm{d})$ was positively related to the rate of purine infusion $(x ; \mathrm{mmol} / \mathrm{d})$ with the regression coefficient indicating the urinary recovery of

Table 1. Urinary excretion of purine derivatives (PD) and creatinine $\left(\mu \mathrm{mol} / \mathrm{W}^{0.75}\right.$ ) in four female camels (Camelus dromedarius) under progressive feeding restriction, from ad libitum feeding to fasting (experiment 1) $\dagger$ (Mean values)

\begin{tabular}{|c|c|c|c|c|c|}
\hline Period & Allantoin & Uric acid & Hypoxanthine + xanthine & Total PD & Creatinine \\
\hline Feeding ad libitum & $493^{a}$ & $20 \cdot 2$ & 35.4 & $549^{a}$ & 329 \\
\hline Restricted ration & $406^{a}$ & 21.5 & $13 \cdot 3$ & $375^{a}$ & 324 \\
\hline Fasted & $231^{\mathrm{b}}$ & $19 \cdot 8$ & $16 \cdot 3$ & $267^{b}$ & 260 \\
\hline SE & 34.5 & $4 \cdot 30$ & 4.50 & $19 \cdot 61$ & $47 \cdot 96$ \\
\hline Significance & * & NS & NS & $\star \star$ & NS \\
\hline
\end{tabular}




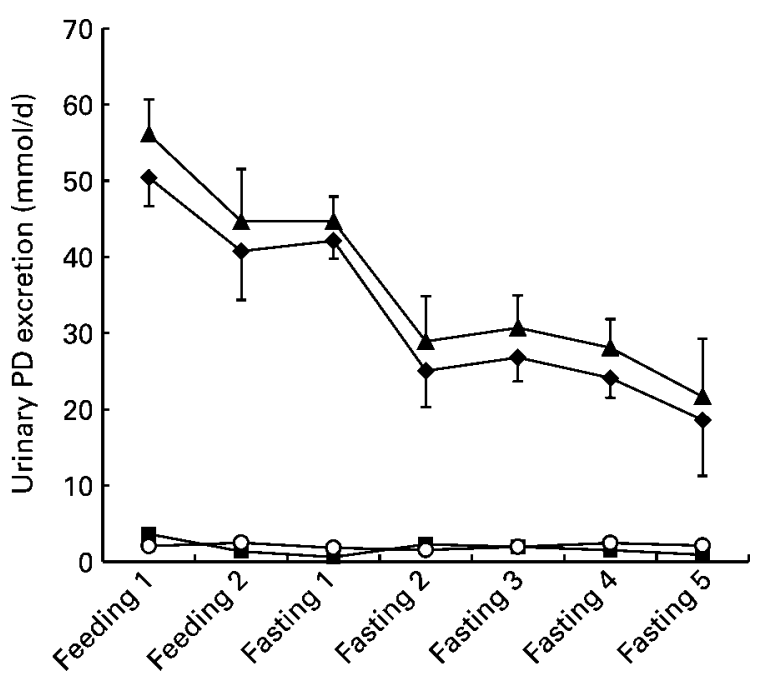

Fig. 1. Experiment 1. Daily excretion $(\mathrm{mmol} / \mathrm{d})$ of allantoin $(\diamond)$, uric acid (O), xanthine + hypoxanthine (ם) and total prine derivatives $(\mathrm{PD} ; \mathbf{\Delta})$ in four female camels (Camelus dromedarius) under progressive feeding restriction from ad libitum feeding to fasting. Values are means, with their standard errors represented by vertical bars.

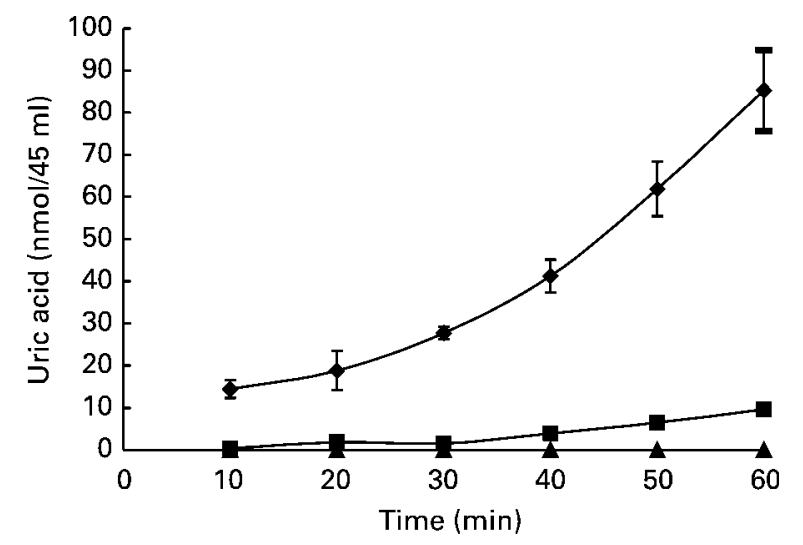

Fig. 2. Experiment 2. Production of uric acid when xanthine was incubated with plasma $(\boldsymbol{\Delta})$, liver tissue $(\boldsymbol{\bullet})$ or intestinal mucosal tissue $(\boldsymbol{\square})$ from three male camels (Camelus dromedarius). Values are means, with their standard errors represented by vertical bars. duodenally infused PB:

$$
\begin{aligned}
y(\mathrm{mmol} / \mathrm{d})= & 22.3(\mathrm{SE} 2.25)+0.63(\mathrm{SE} 0.068) x ; \\
& r 0.924 ; \text { RSD } 3.53 ; n 8 .
\end{aligned}
$$

Most of the changes in total PD excretion resulted from changes in allantoin excretion that increased from $59 \%$ to $67 \%$ of the total PD as the rate of infusion was increased. No significant changes were observed in the excretion of xanthine, hypoxanthine or uric acid. Creatinine excretion was constant throughout the experimental period and therefore the PD:creatinine ratio also increased linearly with increasing duodenal PB administration.

\section{Experiment 4: urinary excretion of purine derivatives at different levels of food intake}

PD excretions at different levels of DOMI are presented in Table 3. The rate of urinary excretion of allantoin increased $(P<0.05)$ with increases in food intake as did total PD excretion $(P<0 \cdot 01)$, whereas rates of excretion of xanthine, hypoxanthine and uric acid were unchanged $(P>0 \cdot 1)$. The positive relationship between DOMI $(\mathrm{kg} / \mathrm{d})$ and PD excretion rate $(\mathrm{mmol} / \mathrm{d})$ is presented in Fig. 3 and the resultant equation was:

$$
\begin{aligned}
\mathrm{PD}= & 14.8(\mathrm{SE} 3 \cdot 20)+11 \cdot 1(\mathrm{SE} 2 \cdot 61) \mathrm{DOMI} ; \\
& \text { r } 0.646 ; \quad \operatorname{RSD} 2 \cdot 57 ; n 16 .
\end{aligned}
$$

The equation indicates there was a mean excretion of $14.8 \mathrm{mmol} / \mathrm{d}$ at zero intake of DOMI corresponding to 170 (SE 31.3) $\mu \mathrm{mol} / \mathrm{kg} \mathrm{W}^{0.75}$. This value was lower than the mean fasting excretion measured in experiment 1 (267 (SE 33.5) $\mu \mathrm{mol} / \mathrm{kg} \mathrm{W}^{075}$ ). Creatinine excretion averaged 364 (SE 15.4) $\mu \mathrm{mol} / \mathrm{kg} \mathrm{W}^{0.75}$ and was not related to food intake.

\section{Chemical composition of microbes extracted from the camel forestomach}

The total $\mathrm{N}$ concentration in rumen bacteria extracted from

\begin{tabular}{|c|c|c|c|c|c|c|}
\hline \multirow[b]{2}{*}{ Camel } & \multirow[b]{2}{*}{ Duodenal flow of RNA (mmol/d) } & \multicolumn{4}{|c|}{ Urinary excretion $(\mathrm{mmol} / \mathrm{d})$} & \multirow[b]{2}{*}{ Recovery* (\%) } \\
\hline & & Allantoin & UA & $\mathrm{X}+\mathrm{HX}$ & PD & \\
\hline \multirow[t]{4}{*}{1} & 0 & $13 \cdot 63$ & $3 \cdot 77$ & $5 \cdot 43$ & $22 \cdot 83$ & - \\
\hline & 18 & $21 \cdot 25$ & 6.98 & $5 \cdot 71$ & 33.94 & 62 \\
\hline & 36 & $37 \cdot 03$ & 6.69 & $6 \cdot 19$ & $49 \cdot 91$ & 75 \\
\hline & 55 & 39.54 & $11 \cdot 21$ & $8 \cdot 23$ & 58.99 & 66 \\
\hline \multirow[t]{4}{*}{2} & 0 & $12 \cdot 23$ & $3 \cdot 22$ & 4.95 & $20 \cdot 40$ & - \\
\hline & 18 & $18 \cdot 51$ & $6 \cdot 27$ & $6 \cdot 02$ & $30 \cdot 80$ & 58 \\
\hline & 36 & 29.06 & 7.98 & $6 \cdot 68$ & $43 \cdot 72$ & 65 \\
\hline & 55 & $30 \cdot 34$ & 11.91 & $9 \cdot 23$ & 54.48 & 62 \\
\hline
\end{tabular}
rumen digesta was $79.6 \mathrm{~g} / \mathrm{kg} \mathrm{DM}$. The concentration of PB

Table 2. Excretion of allantoin, uric acid (UA) and xanthine $(X)$ +hypoxanthine $(H X)$ in urine of two camels (Camelus dromedarius) given a duodenal infusion of RNA (from Torula yeast) (experiment 3)

PD, Purine derivatives.

${ }^{*}$ Recovery of duodenal purines as total PD was calculated as: increase in urinary PD excretion rate/increase in duodenal purine base infusion rate. 
Table 3. Digestible organic matter intake (DOMI) and daily excretion of purine derivatives (PD) in four camels (Camelus dromedarius) offered $40,60,80$ or $100 \%$ of their previously recorded ad libitum intakes (experiment 4)

(Mean values and residual standard deviations)

\begin{tabular}{|c|c|c|c|c|c|c|}
\hline Ration (\% ad libitum)... & 40 & 60 & 80 & 100 & RSD & Significance of the experimental effect \\
\hline DOMI (kg/d) & $1 \cdot 20$ & $1 \cdot 90$ & 2.50 & 3.50 & $0 \cdot 13$ & * \\
\hline \multicolumn{7}{|l|}{ Urinary PD excretion $(\mathrm{mmol} / \mathrm{d})$} \\
\hline Total PD & $27 \cdot 5$ & 34.9 & $45 \cdot 7$ & $52 \cdot 2$ & $7 \cdot 89$ & ** \\
\hline Allantoin & $19 \cdot 1$ & $28 \cdot 4$ & $38 \cdot 3$ & $44 \cdot 6$ & $9 \cdot 20$ & * \\
\hline Uric acid & 3.25 & 2.5 & $2 \cdot 82$ & $1 \cdot 17$ & 1.61 & NS \\
\hline Xanthine + & & & & & & \\
\hline hypoxanthine & $5 \cdot 15$ & 4.03 & $4 \cdot 60$ & $6 \cdot 38$ & $1 \cdot 70$ & NS \\
\hline Creatinine excretion $\left(\mu \mathrm{mol} / \mathrm{kg}\right.$ body weight ${ }^{0.75}$ ) & 371 & 391 & 360 & 333 & 114 & NS \\
\hline
\end{tabular}

${ }^{\star} P<0.05,{ }^{* \star} P<0.01$.

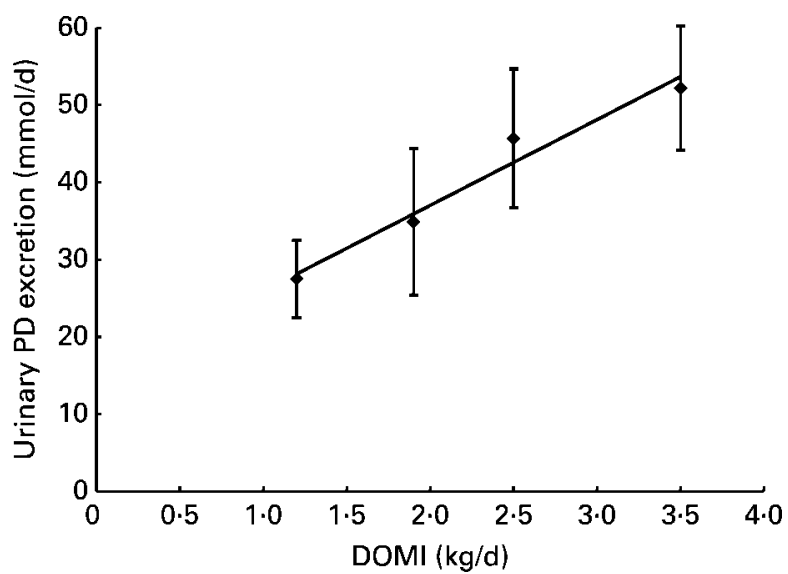

Fig. 3. Experiment 4. Relationship between digestible organic matter intake (DOMI) and urinary excretion of purine derivatives (PD) in four camels (Camelus dromedarius) offered food at 40,60, 80 or $100 \%$ of their previously recorded ad libitum intakes $(y=11.1 x+14.8 ; n 16 ; r 0.646)$. Values are means, with their standard errors represented by vertical bars.

was $100 \cdot 3 \mathrm{mmol} / \mathrm{kg} \mathrm{DM}$, and the resultant $\mathrm{PB}: \mathrm{N}$ ratio was $1 \cdot 26$.

\section{Discussion}

\section{Profile of purine derivatives in urine}

The profile of PD in the urine of the camel was similar to that previously found in the sheep and goat and is consistent with there being a significant level of salvageable PD as a consequence of a low XO activity in the intestinal mucosa (allowing transfer of purines) and in liver tissues (allowing salvage in this organ). This profile is similar to that previously reported for the llama (Bakker et al. 1996).

\section{Xanthine oxidase activity in liver, intestinal mucosa and plasma}

The XO activity in different tissues has been reported for several ruminant species. Mura et al. (1986) did not detect XO activity in gut mucosa or liver tissue in the camel but found low activity in these tissues in zebu cattle. In the present study, low XO activity (units/g wet tissue) was found in gut mucosa (0.005) and moderate activity was found in the liver (0.04; units/g wet tissue). No activity was detected in blood in the present study. In contrast, Al-Khalidi \& Chaglessian (1965) detected significant $\mathrm{XO}$ activity in camel serum. The XO activity profile for the camels in the present study was apparently different from that described for European and zebu cattle but was similar to that for sheep (Chen et al. 1990) and goats (Belenguer et al. 2002). These results suggest that, in camels, exogenous (microbial) PB can pass through the wall of the gastrointestinal tract and become available for direct incorporation into tissue nucleotides by the purine salvage pathway. Moreover, the low XO activity in intestinal tissue is the reason for the low range of PD-irreversible oxidation of tissue nucleotides. This is reflected in the low endogenous PD excretion ( $\mu \mathrm{mol} / \mathrm{kg} \mathrm{W}^{075}$ ) measured in goats (202; Belenguer et al. 2002), sheep (158; Fujihara et al. 1991) and camels (267) compared with higher values measured in cattle (609 for allantoin only; Blaxter \& Wood, 1951).

Urinary excretion of purine derivatives during fasting and in response to different levels of intra-duodenal purine supply

Total PD excretion decreased gradually when food intake was restricted and up to the fifth day of fasting; no significant increases in allantoin excretion were recorded. Results for llamas (Lama glama and L. guanacoe; Bakker et al. 1996), goats (Belenguer et al. 2002) and different species of zebu cattle (Liang et al. 1999) or zebu crossbreed cattle (Ojeda \& Parra, 2000) confirm the validity of the fasting procedure as a means of determining endogenous PD excretion.

In sheep, endogenous PD excretion in fasting animals ( $7 \mathrm{mg} \mathrm{N} / \mathrm{kg} \mathrm{W}^{075}$; Fujihara et al. 1991) was not different from that determined with intragastrically fed animals (9.8 $\mathrm{mg} \mathrm{N} / \mathrm{kg} \mathrm{W}^{075}$; Fujihara et al. 1991). The measured PD excretion in the camel after $5 \mathrm{~d}$ of fasting is probably the best-available estimate of the endogenous excretion.

The relationship between duodenal supply and urinary excretion of PD is given in Table 2. The correlation coefficient was high $(r 0.924)$ as with previous results with other species such as sheep (Chen et al. 1990; Balcells et al. 1991), goats (Belenguer et al. 2002) and either European cattle (Verbic et al. 1990; Orellana Boero et al. 2001) or 
zebu cattle (Pimpa et al. 2001). The good relationship helps to validate the concept of using urinary PD excretion as a predictor of microbial output from the forestomachs. The urinary recovery of duodenally administered $\mathrm{PB}$ in the camel (urinary PD/duodenal PB) was 0.63 (SE 0.068). This was slightly lower than values obtained for goats (0.76; Belenguer et al. 2002), and cattle (0.77-0.90; Verbic et al. 1990; Beckers \& Thewis, 1994; Liang et al. 1999; Orellana Boero et al. 2001) but was within the range for sheep (0.52-0.80\%; Giesecke et al. 1984; Chen et al. 1990; Balcells et al. 1992).

The basal excretion of PD reflected the endogenous contribution to urinary excretion and the 0.63 recovery of administered PD in urine suggests that 0.37 was excreted via non-renal routes. However, for predictive purposes, it is necessary to consider that the host's (endogenous) contribution to urinary excretion could be replaced by exogenous purines. This was also the case in sheep (Chen et al. 1990; Balcells et al. 1991) but not in cattle (Verbic et al. 1990; Orellana Boero et al. 2001) where the XO activity in intestinal mucosa and liver was too high to permit any uptake of salvageable PD (xanthine and hypoxanthine). Thus, the low activity of $\mathrm{XO}$ observed in the present work and in the work of Mura et al. (1986) would place camels in the group of species able to reduce the need for de novo synthesis of purines by making use of the salvage pathways (Balcells et al. 1991). The moderate or low levels of endogenous PD excretion, and the presence of significant amounts of salvageable purine compounds in camel urine is consistent with the conclusion that the camel is similar to sheep in relation to purine excretion modelling.

The effects of endogenous PD excretion in the urine on model predictions of duodenal PB absorption would be less important when animals are fed above maintenance (in sheep; Chen et al. 1990, Balcells et al. 1991). In this case, the amount of absorbed purines $(x ; \mathrm{mmol} / \mathrm{d})$ can simply be estimated as PD excretion $(y ; \mathrm{mmol} / \mathrm{d}) /$ incremental recovery $(0 \cdot 63)$, then $x=y / 0 \cdot 63$. However, in animals fed below maintenance level, the relationship between duodenal purine input and urinary PD output would reflect the biochemical feedback on the de novo synthesis process by the salvage of absorbed exogenous purine by tissues (Nolan, 1999) rather than exogenous absorption.

Finally, if it is assumed that the PB:total $\mathrm{N}$ ratio in mixed microbial materials flowing out of the forestomachs is similar to that determined for fluid-associated microbes (1.26 mmol PB/g N; present study), then microbial $\mathrm{N}$ outflow can be calculated as:

$$
\text { Microbial } \mathrm{N}(\mathrm{g} / \mathrm{d})=x /(0.92 \times 1 \cdot 26)
$$

where 0.92 is the true digestibility of duodenal PB (Chen et al. 1990) and 1.26 is the PB (100.3 $\mu \mathrm{mol} / \mathrm{g}$ DM): $\mathrm{N}$ $(79.6 \mathrm{mg} / \mathrm{g} \mathrm{DM})$ ratio in microbial materials isolated from fluid-associated microbes from the forestomachs. The PB:total $\mathrm{N}$ ratio in microbial materials $(1.26 \mathrm{~mol} \mathrm{~PB} / \mathrm{g} \mathrm{N})$ found in the present study with camels is similar to ratios determined for steers $(1.05-1.23)$, but slightly higher than values for sheep (1.57-2.07; Pérez et al. 1997; Martín-Orúe et al. 1998) and goats (1.97; Belenguer et al.
2002). Moreover, factors other than animal breed such as diet (roughage:concentrate ratio; Martín-Orúe et al. 1998) or time after feeding (Craig et al. 1987) may also be responsible for such differences in this ratio.

\section{Excretion of purine derivatives in response to different levels of food intake}

Net growth and outflow of microbial biomass from the forestomachs is directly related to fermentable energy availability if other nutrients are non-limiting (AFRC, 1993). Positive linear relationships between intakes of digestible DM and urinary PD excretion (Vercoe, 1976) or digestible organic matter and urinary PD excretion or net microbial production have been described for the sheep (Laurent et al. 1983; Han et al. 1992; Balcells et al. 1993), the goat (Lindberg, 1985) and for cattle (Liang et al. 1994). Fig. 3 confirms the linear relationship between DOMI and the urinary excretion of PD and the slope $(11.1 \mathrm{mmol} / \mathrm{kg}$ DOMI represents the efficiency coefficient for net microbial synthesis. The reported value for the camels in the present study was close to that reported for goats $(12.6)$ by Laurent et al. (1983) but lower than values reported for sheep (18.9-22.3; Antoniewicz \& Pisulewski, 1982; Balcells et al. 1993). The PD:DOMI ratio was not constant across experimental treatments and, notably, the highest value was obtained at the lowest level of food intake. Generally, the efficiency of net microbial synthesis increases with increasing food intake (ARC, 1984); however, in the present study where food intake level was below that required for maintenance (in two periods), endogenously synthesised PD may have contributed to the urinary PD excretion with the result that the outflow of microbial purines from the forestomachs was overestimated. The overall efficiency coefficient for microbial protein outflow $(95 \mathrm{~g} / \mathrm{kg}$ DOMI) is lower than the indicative value for cattle and sheep on good-quality mixed diets (130 g/kg DOMI) suggested by ARC (1984) and may indicate that microbial growth in camels is lower than in true ruminants.

To check the reliability of the proposed model, the duodenal flow of microbial $\mathrm{N}$ was estimated from urinary PD excretion and contrasted against maintenance requirements calculated following AFRC (1993) guidelines (Table 4). The net protein requirement for maintenance was assumed to be equivalent to that established for cattle and goats $\left(0.368 \mathrm{~g} / \mathrm{kg} \mathrm{W} \mathrm{W}^{075}\right.$; AFRC 1993). This includes basal endogenous $\mathrm{N} \quad\left(0.350 \mathrm{~g} / \mathrm{kg} \mathrm{W}^{0.75}\right)$ plus dermal losses $\left(0.018 \mathrm{~g} / \mathrm{kg} \mathrm{W} \mathrm{W}^{075}\right)$ and assumes an efficiency of use of metabolisable protein for maintenance purposes of $1 \cdot 0$. In the same way, estimated values of microbial $\mathrm{N}$ were assumed to have an amino acid-N content of 0.75 and to be digested with an efficiency of $0 \cdot 85$. The results of the present study confirm the reliability of the estimated values and indicate that when camels given maintenance rations $(314 \mathrm{~kJ} / \mathrm{kg}$ $\mathrm{W}^{075}$; Guerouali \& Zine Filali, 1992), metabolisable protein from microbes will meet their protein requirements as occurs in other species such as cattle or sheep (Ørskov, 1982).

Creatinine is a metabolic product of creatine and phosphocreatine, both being found almost exclusively in muscle (Van Niekerk et al. 1963). Thus, creatinine production and urinary excretion are proportional to muscle 
Table 4. Feeding level, purine derivative (PD) excretion in urine, PD:creatinine ratio in urine samples and predicted net microbial nitrogen (MN) outflow from the forestomachs of four camels (Camelus dromedarius) offered food at 40, 60,80 or $100 \%$ of their previously recorded ad libitum intake (experiment 4)

(Mean values and residual standard deviations)

\begin{tabular}{|c|c|c|c|c|c|c|}
\hline Ration ( $\%$ ad libitum)... & 40 & 60 & 80 & 100 & RSD & Significance of the experimental effect \\
\hline Feeding level† & 0.75 & $1 \cdot 12$ & 1.49 & $1 \cdot 87$ & 0.48 & * \\
\hline PD excretion $(\mathrm{mmol} / \mathrm{d})$ & $27 \cdot 5$ & 34.9 & $47 \cdot 7$ & $52 \cdot 2$ & $11 \cdot 38$ & * \\
\hline PD:DOMI (mmol/kg) & 31.37 & $25 \cdot 14$ & $25 \cdot 02$ & $22 \cdot 32$ & $3 \cdot 80$ & NS \\
\hline PD:creatinine (mol/mol) & 0.72 & 0.87 & $1 \cdot 24$ & 1.53 & 0.37 & * \\
\hline Estimated $\mathrm{MN} \ddagger(\mathrm{g} / \mathrm{d})$ & $37 \cdot 65$ & $47 \cdot 78$ & 62.57 & 71.47 & $15 \cdot 07$ & * \\
\hline Microbial MP§ $(\mathrm{g} / \mathrm{d})$ & 24.09 & 30.57 & $40 \cdot 04$ & $45 \cdot 74$ & $9 \cdot 64$ & * \\
\hline MP requirements $\|(\mathrm{g} / \mathrm{d})$ & $35 \cdot 77$ & $35 \cdot 77$ & 35.77 & $35 \cdot 77$ & - & - \\
\hline
\end{tabular}

MP, metabolisable protein.

${ }^{\star *} P<0.05$.

† Metabolisable energy (ME) intake/ME requirements for maintenance $\left(0.314 \mathrm{MJ} / \mathrm{kg}\right.$ body weight ${ }^{0.75}$, Guerouali \& Zine Filali, 1992$)$.

$\ddagger \mathrm{MN}$ outflow $=(\mathrm{PD} / 0.63) /(0.92 \times 1.26)=1.37 \mathrm{PD}(\mathrm{mmol} / \mathrm{d})$

$\S$ MP supply from microbes $=\mathrm{MN} \times 0.75 \times 0.85$ (AFRC, 1993).

$\|$ Maintenance $\mathrm{N}$ requirements $=0.368 \mathrm{~g} / \mathrm{kg}$ body weight ${ }^{0.75}$.

mass and vary little from day to day in response to changing food or nutrient supply. If daily creatinine excretion is predictable, then the creatinine:PD ratio in 'spot' samples of urine can be used to predict daily PD excretion which in turn can be used to predict the daily outflow of purines and microbial protein from the forestomachs.

In summary, the present work has defined the relationship between intestinal supply of $\mathrm{PB}$ and the urinary excretion of their derivatives. The tissue $\mathrm{XO}$ activity, the recovery of duodenally infused purines and also the endogenous losses of PD estimated in fasting camels suggest that camels and sheep are closely similar in the way they metabolise purines.

\section{Acknowledgements}

The present study was supported by ACSAD and the IAEA via research contract MOR10564 (Morocco) and AA.EE/ AECI 229-188 and CICYT- PB 98-1601 (Spain).

\section{References}

AFRC (1993) Energy and Protein Requirements of Ruminants. An Advisory Manual Prepared by the AFRC Technical Committee on Responses to Nutrients. Wallingford, UK: CAB International.

Al-Khalidi UAS \& Chaglessian TH (1965) The species distribution of xanthine oxidase. Biochem J 97, 318-320.

Antoniewicz AM \& Pisulewski PM (1982) Measurement of endogenous allantoin excretion in sheep urine. J Agric Sci (Camb) 98, 221-223.

ARC (1984) The Nutrient Requirement of Ruminant Livestock, Suppl. 1., Wallingford, UK: Commonwealth Agricultural Bureaux.

Association of Official Analytical Chemists (1980) Official Methods of Analysis, 13th ed, Washington, DC: AOAC.

Bakker ML, Chen XB, Kyle DJ, Ørskov ER \& Bourke DA (1996) Urinary and plasma purine derivatives in fed and fasted llamas (Lama glama and L. guanacoe). Comp Biochem Physiol 113B, 367-374.

Balcells J, Guada JA, Castrillo C \& Gasa J (1991) Urinary excretion of allantoin and allantoin precursors by sheep after different rates of purine infusion into the duodenum. J Agric Sci (Camb) 116, 309-317.
Balcells J, Guada JA, Castrillo C \& Gasa J (1993) Rumen digestion and urinary excretion of purine derivatives in response to urea supplementation of sodium-treated straw fed to sheep. Br J Nutr 69, 721-732.

Balcells J, Guada JA, Peiró JM \& Parker DS (1992) Simultaneous determination of allantoin and oxypurines in biological fluids by high-performance liquid chromatography. J Chrom 575, $153-157$.

Beckers Y \& Thewis A (1994) Excretion of purine derivatives in urine of Belgian blue bull following duodenal infusion of purines from Torula yeast. Proc Soc Nutr Physiol 3, 235.

Belenguer A, Yañez D, Balcells J, Ozdemir Baber NH \& Gonzalez Ronquillo M (2002) Urinary excretion of purine derivatives and prediction of rumen microbial outflow in goats. Livest Prod Sci 77, 127-135.

Blaxter KL \& Wood WA (1951) The nutrition of the young Ayrshire calf. 1. The endogenous nitrogen and basal energy metabolism of the calf. Br J Nutr 5, 11-25.

Chen X, Samaraweera L, Kyle DJ, Ørskov ER \& Abeygunawardene H (1996) Urinary excretion of purine derivatives and tissue xanthine oxidase activity in buffaloes, with special reference to differences between buffaloes and Bos Taurus. Br J Nutr 75, 397-407.

Chen XB, Hovell FD DeB, Ørskov ER \& Brown DS (1990) Excretion of purine derivatives by ruminants: effect of exogenous nucleic acid supply on purine derivative excretion by sheep. Br J Nutr 63, 131-142.

Craig WN, Brown DR, Broderick GA \& Ricker DB (1987) Postprandial compositional changes of fluid and particle associated ruminal microorganism. J Anim Sci 65, 1042-1048.

Fujihara T, Matsui T \& Harumoto T (1991) Urinary excretion of purine derivatives and blood plasma level of allantoin in sheep and goats during fasting. In Proceedings of the Sixth International Symposium of Protein Metabolism and Nutrition, pp. 170-172 [BO Eggum, S Boisen, Ch Borsting, A Danfaer and T Hvelplung, editors]. Herning, Denmark: European Association for Animal Production.

Furth-Walker D \& Amy NK (1987) Regulation of xanthine oxidase activity and inmunologically detectable protein in rats in response to dietary protein and iron. J Nutr 117, 1697-1705.

Giesecke D, Stangassinger M \& Tiemeyer W (1984) Nucleic acid digestion and urinary purines metabolites in sheep nourished by intragastric infusion. Can J Anim Sci 64, 144-145.

Guerouali A \& Zine Filali R (1992) Maintenance energy requirements of the dromedary camel. In Proceedings of the First International Camel Conference, pp. 251-254 [WR Allen, AJ Higgins, IG Mayhew, DH Snow and 
JF Wade, editors]. Newmarket, UK: R\&W Publications (Newmarket) Ltd.

Han YK, Shin HT \& Landis J (1992) Effect of level of food intake on the excretion of purine derivatives on purine derivatives to creatinine ratio in the urine sheep. Asian-Aust J Anim Sci 5, 465-468.

Laurent F, Blanchart G \& Vignon B (1983) Relation entre l'excretion urinaire d'allantoine et l'azote chez le chevre laitiere (Relationship between the urinary excretion of allantoin and nitrogen in lactating goats). In IV Symposium International de Metabolisme et Nutrition Azotés, vol. 2, pp. 175-178 [M Arnal, R Pion and D Bonin, editors]. Clermont-Ferrand, France: EEAP.

Liang JB, Matsumoto M \& Young BA (1994) Purine derivative excretion and ruminal microbial yield in Malaysian cattle and swamp buffalo. Anim Feed Sci Technol 47, 189-199.

Liang JB, Pimpa O, Abdullah N, Jelan ZA \& Nolan JV (1999) Estimation of rumen microbial protein production from urinary purine derivatives in zebu cattle and water buffalo. In Nuclear Based Technologies for Estimating Microbial Protein Supply in Ruminant Livestock, IAEA-TECDOC-1093, pp. 35-42 Vienna: International Atomic Energy Agency.

Lindberg JE (1985) Urinary allantoin excretion and digestible organic matter intake in dairy goats. Swedish J Agric Res 15, 31-37.

Martín Orúe SM, Balcells J, Guada JA \& Castrillo C (1995) Endogenous purine and pyrimidine derivative excretion in pregnant sows. Br J Nutr 73, 375-385.

Martín Orúe SM, Balcells J, Zakraoui F \& Castrillo C (1998) Quantification and chemical composition of mixed bacteria harvested from solid fractions of rumen digesta: effect of detachment procedure. Anim Feed Sci Technol 71, 269-282.

Mura U, Osman AM, Mohamed AS \& Ipata PL (1986) Studies on purine turnover in the camel (Camelus dromedarius) and zebu (Bos indicus). Comp Biochem Physiol 84, 589-593.

Nolan JV (1999) Prediction of rumen microbial outflow based on urinary excretion of purine derivatives. In Nuclear Based Technologies for Estimating Microbial Protein Supply in Ruminant Livestock, IAEA-TECDOC-1093, pp. 9-20. Vienna: International Atomic Energy Agency.

Ojeda A \& Parra O (2000) Urinary excretion of purine derivatives as an index of microbial protein supply in cross-bred
(Bos indicus) cattle in tropical environment. In Nuclear Based Technologies for Estimating Microbial Protein Supply in Ruminant Livestock, IAEA-TECDOC-1093, pp. 59-68. Vienna: International Atomic Energy Agency.

Orellana Boero P, Balcells J, Martín-Orúe S, Liang JB \& Guada JA (2001) Excretion of purine derivatives in cows: endogenous contribution and recovery of exogenous purine bases. Livest Prod Sci 68, 243-250.

Ørskov ER (1982) Protein Nutrition in Ruminants. London: Academic Press.

Pérez JF, Balcells J, Guada JA \& Castrillo C (1997) Rumen microbial production estimated either from urinary purine derivative excretion or from direct measurements of ${ }^{15} \mathrm{~N}$ and purine bases as microbial markers: effect of protein source and rumen bacterial isolates. Anim Sci 65, 225-236.

Pimpa O, Liang JB, Jelan ZA \& Abdullah N (2001) Urinary excretion of duodenal purine derivatives in Kedah-kelantan cattle. Anim Feed Sci Technol 92, 203-214.

Reeds PJ, Burrin DG, Stall B, Jagoor F, Wykes I, Henay J \& Frazer M (1997) Enteral glutamate is the preferential source of mucosal glutathione synthesis in fed piglets. Am J Physiol 273, 408-415.

Rowell JG \& Walters DE (1976) Analysing data with repeated observations on each experimental unit. J Agric Sci (Camb) 87, 423-432.

Steel RGD \& Torrie JH (1980) Principles and Procedures of Statistics: a Biometrical Approach, 2nd ed. New York: McGrawHill Inc.

Technicon Instruments Co. (1979) Uric Acid. Technicon method no. SD4-0013 FM9. Tarrytown, NY: Technicon Instruments Co.

Van Niekerk BDH, Reid JT, Bensadoun A \& Paladines OL (1963) Urinary creatinine as an index of body composition. J Nutr 79, 463-473.

Verbic J, Chen XB, MacLeod NA \& Ørkov ER (1990) Excretion of purine derivatives by ruminants. Effect of microbial nucleic acid infusion on purine derivative excretion by steers. J Agric Sci (Camb) 114, 243-248.

Vercoe JE (1976) Urinary allantoin excretion and digestible drymatter intake in cattle and buffalo. J Agric Sci (Camb) 86, 613-615.

Young EG \& Conway CF (1942) On the estimation of allantoin by the Rimini-Schryver reaction. J Biol Chem 142, 839-852. 